\title{
ÁLLAMSZOCIALIZMUS ÉS REGIONÁLIS GAZDASÁGTAN
}

\author{
Miklóssy Endre
}

Az alapkérdés az, hogy lehet-e narancsot termelni az Északi Sarkon.

Természetesen lehet. Meg kell építeni az üvegházat, odavinni a termốtalajt, a vizet, az energiát, el kell ültetni a magot, és 15 év múlva már ontja is a fa a narancsot.

De van egy másik alapkérdés is. Az, hogy érdemes-e?

Ha valaki felteszi ezt a kérdést, egyszerủ rá a válasz. De ha nem teszik fel, akkor természetesen fölösleges - egyebek mellett - a regionális gazdaságtan is, hiszen bármit, bárhol meg lehet csinálni, amit akarunk.

Az államszocializmus egészének a tárgyunkat illetố legfontosabb sajátossága az, hogy érzéketlen a ráfordítások iránt. Ez az érzéketlenség azzal jár, hogy a redisztribúciós elvû́ gazdaság ugyanazt az eredményt csak jóval nagyobb ráfordítás árán tudja elérni, mint a piacelvũ.

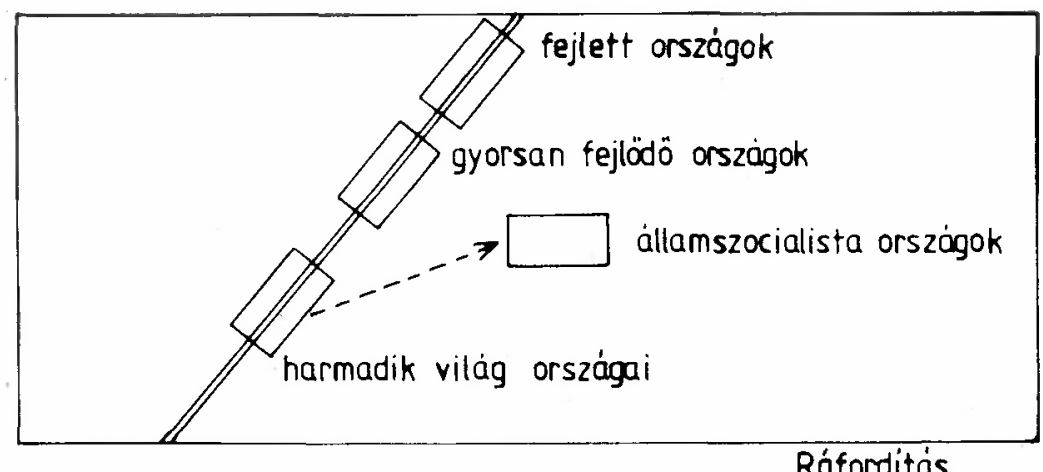

1. ABRA

Ha összehasonlítjuk a nemzetközi statisztikák alapján a GDP értékét az anyag- és energiaráfordítással, a fajlagos munkaigénnyel, a környezetterheléssel, akkor az államszocialista országok jellegzetes elkülönülését tapasztalhatjuk.

Valaha ezek az országok is rajta voltak az arányosságot kifejezỏ alapgörbén, és onnan éppen a többletráfordítások hatására távolodtak el.

Ez a hatékonyságromlás olyan nagyfokú is lehet, midốn már semmiféle ráfordítástöbblettel nem érhetô el többleteredmény.

Magyarország nemzeti össztermékének az értéke 1984-86 között 7 milliárd Ft-tal nớtt, és ehhez 7 milliárd dollár hitelt kellett fölvenni. Ennél a bécsi lottó is többet hozott volna...

Ennek a nemzetgazdasági alapténynek igen jelentốsek a regionális következményei is. Mert ha igaz is az, hogy bárhol bármit lehet csinálni, még akkor is fennáll, hogy a tevékenységek 
ráfordításai közötti különbség — a tevékenység és a helyi adottságok függvényében — igen nagy lehet.

Kitalálhatunk teszem azt olyan szabályozórendszert, hogy még a Kékestetôn is érdemes legyen kukoricát termelni. De itt a baj - ha már nem tudjuk tovább növelni a ráfordításokat -, akkor az így profilírozott hegycsúcs gazdasági válságterületté fog válni.

Így az államszocializmusnak van egy igen jellegzetes területi alapkövetkezménye is, ami akkor válik láthatóvá, ha a gazdaság vizsgálatába bevonjuk a piacot, vagyis az eredményességet.

1989-ben kellett egy vizsgálatot készítenem az úgynevezett ,,gazdasági válságtérségek” lehatárolására. Ennek egy fázisában városkörzeti bontásban megnéztem az ipari eszközállomány összefüggését a gazdasági eredménnyel. Csak az országos átlaghoz lehetett viszonyítani, de az eredmény így is rendkívül tanulságos.

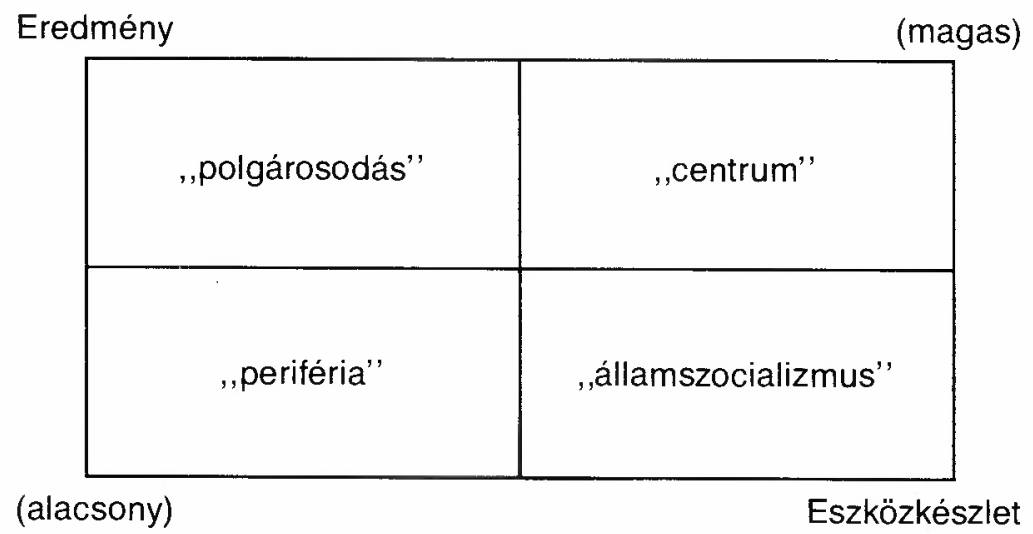

2. ÁBRA

Az egyik meghatározó ok a perifériák kvázi-gyarmati függésben tartása a ,,centrumtérségek" javára. A kettô viszonya mindenesetre nagyjából megfelel a nemzetközi eredmény/ráfordítás görbének.

A másik fontos meghatározó a szocialista nagyipar ,,bázisának”, az alapanyag és kitermelốiparnak a jelenléte, ami hatalmas ráfordítás (lekötött eszközérték) mellett minimális eredményt produkál.

A harmadik meghatározó: vannak olyan területek, amelyeket a központi fejlesztéspolitika ugyan elhanyagolt, de nem szívta el teljes mértékben az erőforrásait. Ezek a piacra vannak kényszerítve, ráfordításaikat minimalizálniuk kell.

A vállalkozók minden kétséget kizáróan ebben a szektorban találhatók.

Bizonyos, hogy ilyen eredményeket kapnánk más gazdasági ágazatok-tevékenységek vizsgálatánál is.

Bizonyos továbbá, hogy ezek a területi különbségek komplexek is. Ahol például az ipari eszközérték magas, ott egyszersmind más fejlesztések is voltak, tehát az infrastruktúrának is fejlet- 
tebbnek kell lennie, Így, ha az egész nemzetgazdaság területi eredményeit vizsgálnánk, még markánsabbak lennének a területi hatékonysági különbségek.

Ez az a pont, ahol a mai Magyarországon a regionális gazdaságtan pótolhatatlanul fontossá válik.

Van egy kritikai irányzat a nemzetközi szakirodalomban, amely a regionális gazdasági vizsgálatokat ,,bolhapatkolásnak”, a rájuk alapozott akcióterveket pedig a zû́rzavar fokozásának tartja (pl.: Barras-Broadent: The analysis in English structure plans, In: Urban Studies, 1979/1). De nálunk, ahol az eredmény és a ráfordítás közötti arányok ilyen mértékben eltorzulhattak, bizonnyal nem ez a helyzet.

Nézzük meg a hazánk elổt álló fố társadalmi és gazdasági programot, az Európához való felzárkózást, az eredmény/ráfordítás görbék függvényében.

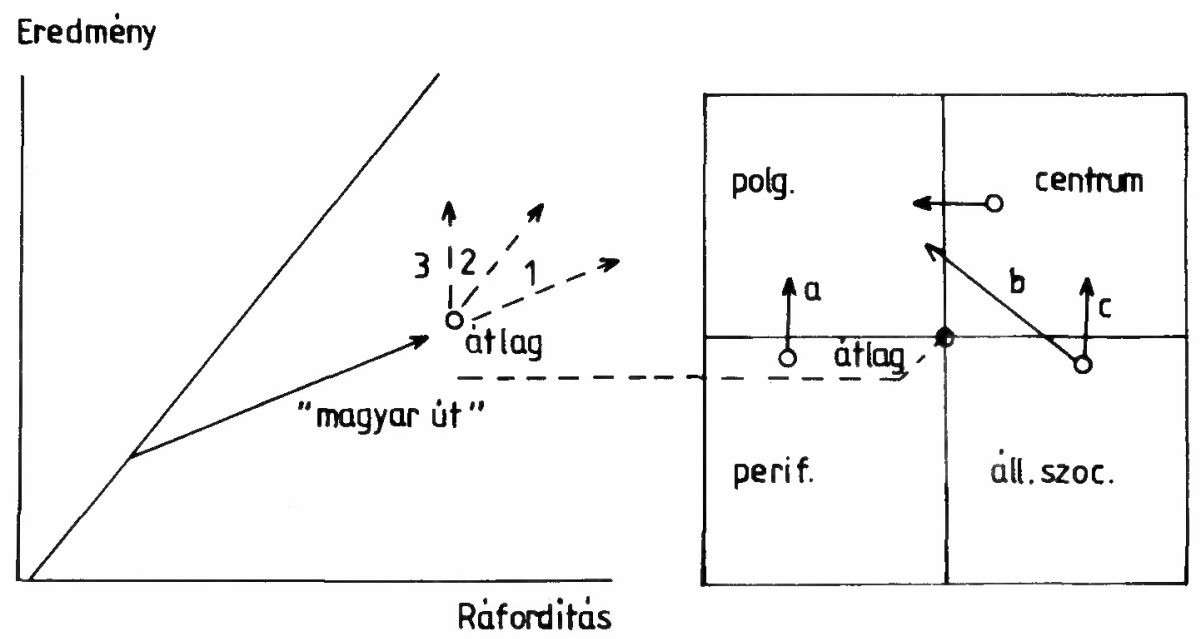

3. ÁBRA

Ha folytatódnék az eddigi ráfordításérzéketlen tendencia (1), akkor gyorsuló ütemben távolodnánk még tovább a világtól. De még ha a ráfordításnövekedés a továbbiakban arányos maradna is az eredménnyel (2), láthatóan az sem csökkentené a lényegi különbséget. 
Csak ha sikerül a ráforditásokat is csökkenteni, reménykedhetünk a felzárkózásban (3), ami sémánk szerint nem egyéb mint visszatérés az , ,alapgörbéhez".

Regionális osztályzásunk szerint ez azt jelenti: a térségek fejlôdését mindenképpen a ,,polgárosodás" típusú felé kell irányítani (a., b., d. irányok).

Az államszocialistának nevezett alapanyagipari térségek számára - az ott kiépített jó infrastruktúra és egyéb adottságok bázisán - egy centrumirányú fejlődési pálya is lehetséges (c.). Ami eleve nem jöhet számításba, az az , államszocialista" irányú fejlôdés, valamint a perifériatérség ,,centrumtérséggé” fejlesztése.

(Ez utóbbinál arra kell gondolnunk, hogy az ilyen típusú fejlődés az elmúlt évtizedekben mindig a paternalista állami gyámkodás eredménye volt, a benne rejlố hatékonyságcsökkenési fố tendenciával egyetemben.)

Értelmezésünk szerint a regionális gazdaságtan sok segítséget nyújthat a területek helyzetének és szükséges fejlổési stratégiáinak a feltárásában. A kialakult egyenlôtlenségrendszerek ugyanis akkorák, a latens szubvencionális rendszer pedig oly erôs, hogy segítség nélkül aligha várható, hogy pusztán a fölszabaduló piac kompenzálni legyen képes ezeket.

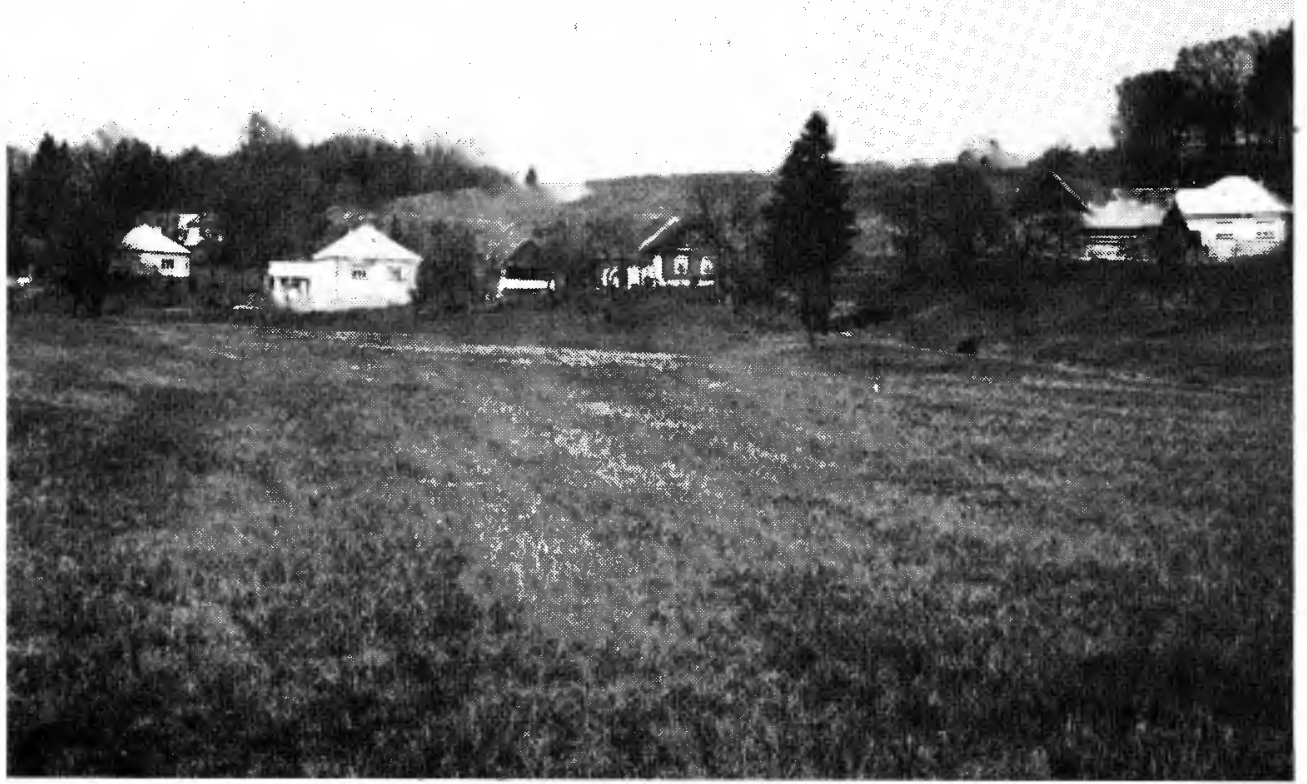

Szórványok közelrôl (Apátistvánfalva) 